\title{
Evaluation of tests performed to confirm the position of the Veress needle for creation of pneumoperitoneum in selected patients: a prospective clinical trial ${ }^{1}$
}

\author{
Valor das provas de posicionamento da ponta da agulha de Veress para a criação do \\ pneumoperitônio artificial em pacientes selecionados: ensaio clínico prospectivo
}

\author{
Otávio Cansanção de Azevedo², João Luiz Moreira Coutinho Azevedo ${ }^{3}$,Albino Augusto Sorbello ${ }^{4}$, Gustavo Peixoto Soares \\ Miguel $^{5}$, Jorge Luis Wilson Junior ${ }^{6}$, Antônio Cláudio de Godoy ${ }^{7}$
}
1. Research performed at the Service of Surgical Gastroenterology, Civil Servant Hospital of the State of São Paulo (HSPE) and Service of Video Surgery, Division of Operative Technique and Experimental Surgery, Federal University of São Paulo (UNIFESP). São Paulo, Brazil.
2. MD, Fellow PhD degree in Surgery, UNIFESP. São Paulo, Brazil.
3. MD, Master and PhD, Associate Professor of Surgery, Chief of the Center of Minimally Invasive Surgery, Division of Operative Techniques and Experimental Surgery, Department of Surgery, (UNIFESP). São Paulo, Brazil.
4. MD, PhD. Chief of Division of Laparoscopy, Service of Surgical Gastroenterology, HSPE. São Paulo, Brazil.
5. MD, Fellow PhD degree, UNIFESP. São Paulo, Brazil.
6. Graduate Student, UNIFESP. São Paulo, Brazil.
7. Director, Service of Surgical Gastroenterology, HSPE. São Paulo, Brazil.

\begin{abstract}
Purpose: To evaluate tests performed to confirm the position of the Veress needle inserted into the left hypochondrium for creation of pneumoperitonium. Methods: One hundred patients were submitted to laparoscopic procedure with left hypochondrium puncturing. Needle positioning tests were evaluated. The aspiration test was considered positive when organic material was aspirated; the injection test was considered positive when no increased resistance to liquid injection was observed; the recovery test was considered positive when the liquid injected was not recovered; the saline drop test was considered positive when drops of saline in the syringe disappeared quickly; the initial intraperitoneal pressure test was considered positive when pressure levels were $£ 8 \mathrm{mmHg}$. A positive aspiration test indicated iatrogenic injury, whereas a positive result in any of the other tests indicated that the tip of the needle was correctly positioned in the peritoneal cavity. Sensitivity (SE), specificity (SP), positive predictive value (PPV) and negative predictive value (NPV) of the tests were calculated by correlating results considered true positives (a), false positives (b), false negatives (c) and true negatives (d), according to the formulas: $\mathrm{SE}=[\mathrm{a} /(\mathrm{a}+\mathrm{c})] \mathrm{x} 100$; $\mathrm{SP}=[\mathrm{d} /(\mathrm{b}+\mathrm{d})] \mathrm{x} 100 ; \mathrm{PPV}=[\mathrm{a} /(\mathrm{a}+\mathrm{b})] \mathrm{x} 100$; $\mathrm{NPV}=[\mathrm{d}(\mathrm{c}+\mathrm{d})] \mathrm{x} 100$. Results: With regard to the aspiration test, SE and PPV were not applicable, SP was $100 \%$ and NPV was $100 \%$. With regard to the injection test, SE was $0 \%$, SP was $100 \%$, PPV was inexistent and NPV was $90 \%$. Both recovery and saline drop tests yielded the following results: SE was $50 \%$, SP was $100 \%$, PPV was $100 \%$ and NPV was $94.7 \%$. The initial intraperitoneal pressure test yielded the following results: SE, SP, PPV and NPV were $100 \%$. Conclusions: When inserting the Veress needle into the left hypochondrium, a negative aspiration test guarantees the absence of iatrogenic injury; the injection test is not reliable to determine incorrect needle positioning, but it accurately detects correct needle positioning; recovery and saline drop tests are not reliable to determine correct needle positioning, but they accurately detect incorrect needle positioning; the initial intraperitoneal pressure test is reliable to determine both correct and incorrect needle positioning, and proved to be the most reliable of the tests analyzed.
\end{abstract}

Key words: Laparoscopy. Surgical Procedures, Operative. Pneumoperitoneum, Artificial. Punctures

\section{RESUMO}

Objetivo: Avaliar provas de posicionamento da agulha de Veress introduzida no hipocôndrio esquerdo para criação de pneumoperitônio. Métodos: Cem pacientes foram submetidos a laparoscopia com punção no hipocôndrio esquerdo. Provas de posicionamento da agulha foram avaliadas. A prova da aspiração foi considerada positiva quando sugava-se material orgânico; a prova da resistência foi considerada positiva quando apenas pouca pressão à infusão de líquido era observada; a prova de recuperação foi considerada positiva quando o líquido infundido não era recuperado; a prova do gotejamento foi considerada positiva quando gotas depositadas na agulha escoavam rapidamente; a prova da pressão intraperitoneal inicial foi considerada positiva quando os níveis observados eram d” $8 \mathrm{mmHg}$. Uma prova de aspiração positiva indicava iatrogenia, ao passo que resultados positivos em todas as outras provas indicavam que a ponta da agulha estava adequadamente posicionada na cavidade peritoneal. Foram calculadas a sensibilidade (S), especificidade (E), valores preditivos positivos (VPP) e negativos (VPN) das provas, mediante correlação dos resultados verdadeiro-positivos (a), falso-positivos (b), falso-negativos (c) e verdadeiro-negativos (d), segundo as fórmulas: $\mathrm{S}=[\mathrm{a} /(\mathrm{a}+\mathrm{c})] \mathrm{x} \mathrm{100;} \mathrm{E}=[\mathrm{d} /$ $(b+d)]$ x 100; VPP = [a/(a + b)] x 100; VPN = [d(c+d)] x 100. Resultados: Na prova da aspiração, constatou-se que S e 
VPP não puderam ser aplicados, e que $\mathrm{E}=100 \%$ e VPN = 100\%. Na prova da resistência, $\mathrm{S}=0 \%, \mathrm{E}=100 \%$, VPP = não existiu e VPN $=90 \%$. Tanto na prova da recuperação como na do gotejamento, $\mathrm{S}=50 \%, \mathrm{E}=100 \%$, VPP $=100 \%$ e VPN $=94,7 \%$. Na da pressão inicial, S, E, VPP e VPN = 100\%. Conclusões: Na punção no hipocôndrio esquerdo, um resultado negativo na prova da aspiração garante ausência de iatrogenia; a prova da resistência não indica com certeza o mau posicionamento da agulha, mas indica corretamente seu bom posicionamento; as provas da recuperação e do gotejamento não reconhecem bem o adequado posicionamento da agulha, mas detectam com segurança seu inadequado posicionamento; a prova da pressão inicial indica com segurança tanto o mau como o bom posicionamento da agulha, sendo a prova mais confiável dentre as estudadas.

Descritores: Laparoscopia. Procedimentos Cirúrgicos Operatórios. Pneumoperitônio Artificial. Punções.

\section{Introduction}

Creation of a pneumoperitoneum is the most critical step of a laparoscopic procedure ${ }^{1}$. There is still no consensus with regard to the best method of gaining access to the peritoneal cavity for creation of the pneumoperitoneum ${ }^{2}$. The closed technique, with the insertion of a Veress needle, is the most frequently used method $^{3-5}$. After insertion and during insufflation, however, the exact position of the needle tip is not always known. Errors in puncturing and insufflations are frequent, and may cause severe iatrogenic injuries ${ }^{5}$.

There are reports of injury to the great vessels and consequent difficulty in diagnosing it correctly, which is mainly due to the retroperitoneal position of the vessels ${ }^{6,7}$.

Major vascular injuries caused by the insertion of the Veress needle into the abdominal midline occur even in the hands of experienced surgeons. Schafer et al. ${ }^{8}$ (2001) analyzed 26 major vascular injuries and reported that only four of them (15\%) had been caused by inexperienced surgeons (surgeons who had performed fewer than 50 laparoscopic procedures). The other 22 injuries (85\%) had been caused either by experienced surgeons (those who had performed between 51 and 100 procedures) or very experienced surgeons (over 100 procedures performed).

Thus, it is essential that the position of the needle tip after insertion be determined as accurately as possible. Needle positioning tests prior to insufflation are recommended in textbooks, and further studies are necessary in order to evaluate these tests.

The objective of this study was to evaluate five tests that are used to confirm the correct position of the Veress needle inside the peritoneal cavity.

\section{Methods}

A total of 100 patients were included in the present study. Said patients had been scheduled to undergo laparoscopic procedures, performed by the same surgeon, at the Surgical Gastroenterology Service of The Civil Servant Hospital of the state of São Paulo (HSPE). All patients were over 18 and non-obese (body mass index lower than $30 \mathrm{Kg}$ / $\mathrm{m}^{2}$ ), with no previous peritonitis or peritoneal cavity surgery. This study was approved by the Research Ethics Committees of the Health Care Institute for the State Civil Servant (protocol n. 045/03), and of the Federal University of São Paulo (protocol n. 1405/03). Table 1 shows the demographic data from patients of our sample. A dosage of $0.1 \mathrm{mg} / \mathrm{Kg}$ of midazolam was administered to patients 30 minutes before anesthesia. For induction of anesthesia, doses of $2 \mathrm{mg} / \mathrm{Kg}$ of propofol and of $0.5 \mathrm{mcg} / \mathrm{Kg}$ of fentanyl were used. For curarization, a dosage of $0.5 \mathrm{mg} / \mathrm{kg}$ of atracurium was used. Patients were submitted to general anesthesia with orotracheal intubation and controlled mechanical ventilation. Then, an orogastric tube was inserted for aspiration of the stomach contents.

TABLE 1 - Descriptive statistics of the demographic data from patients of the sample

\begin{tabular}{ll}
\hline Parameters & $(\mathrm{n}=100)$ \\
\hline Age (years) & \\
mean (SD) & $53.7(13.1)$ \\
minimum-maximum & $27-77$ \\
\hline Sex - $\mathrm{n}(\%)$ & 58 \\
female & 42 \\
male & \\
\hline BMI (kg/m $\left.{ }^{2}\right)$ & $25.4(2.4)$ \\
mean (SD) & $20.6-29.7$ \\
minimum-maximum & \\
\hline Height (m) & $1.64(0.09)$ \\
mean (SD) & $1.45-1.87$ \\
minimum-maximum & \\
\hline Weight (kg) & $68.7(9.8)$ \\
mean (SD) & $49.5-90.0$ \\
minimum-maximum & \\
\hline Intervention - $\mathrm{n}(\%)$ & 80 \\
Cholecystectomy & 9 \\
Esophagogastroplasty & 3 \\
Bilat ing herniorrhaphy & 8 \\
Unilat ing herniorrhaphy &
\end{tabular}

$\mathrm{n}=$ number of patients; $\mathrm{SD}=$ standard deviation; \%=percentage; bilat=bilateral; unilat=unilateral; ing=inguinal

A Veress needle (Figure 1) was inserted into the left hypochondrium (Figure 2), and the recommended tests were performed to check the position of the needle tip prior to insufflation of the peritoneal cavity. The following tests were performed, in the sequence presented: aspiration test (AT) (Figure 3-I), injection test (IT) (Figure 3-II), recovery test (RT) (Figure 3-III), saline drop test (SDT) (Figure 3-IV) and initial intraperitoneal pressure test (IIPT). Injection, recovery and saline drop tests were performed and recorded according to a pre-established protocol, one after another, regardless of the results (positive or negative). After performing these tests, the insufflator was set at a flow rate of $1.2 \mathrm{~L} / \mathrm{min}$ and maximum pressure of $12 \mathrm{mmHg}$. The equipment was then turned on, and IIPT was performed. 

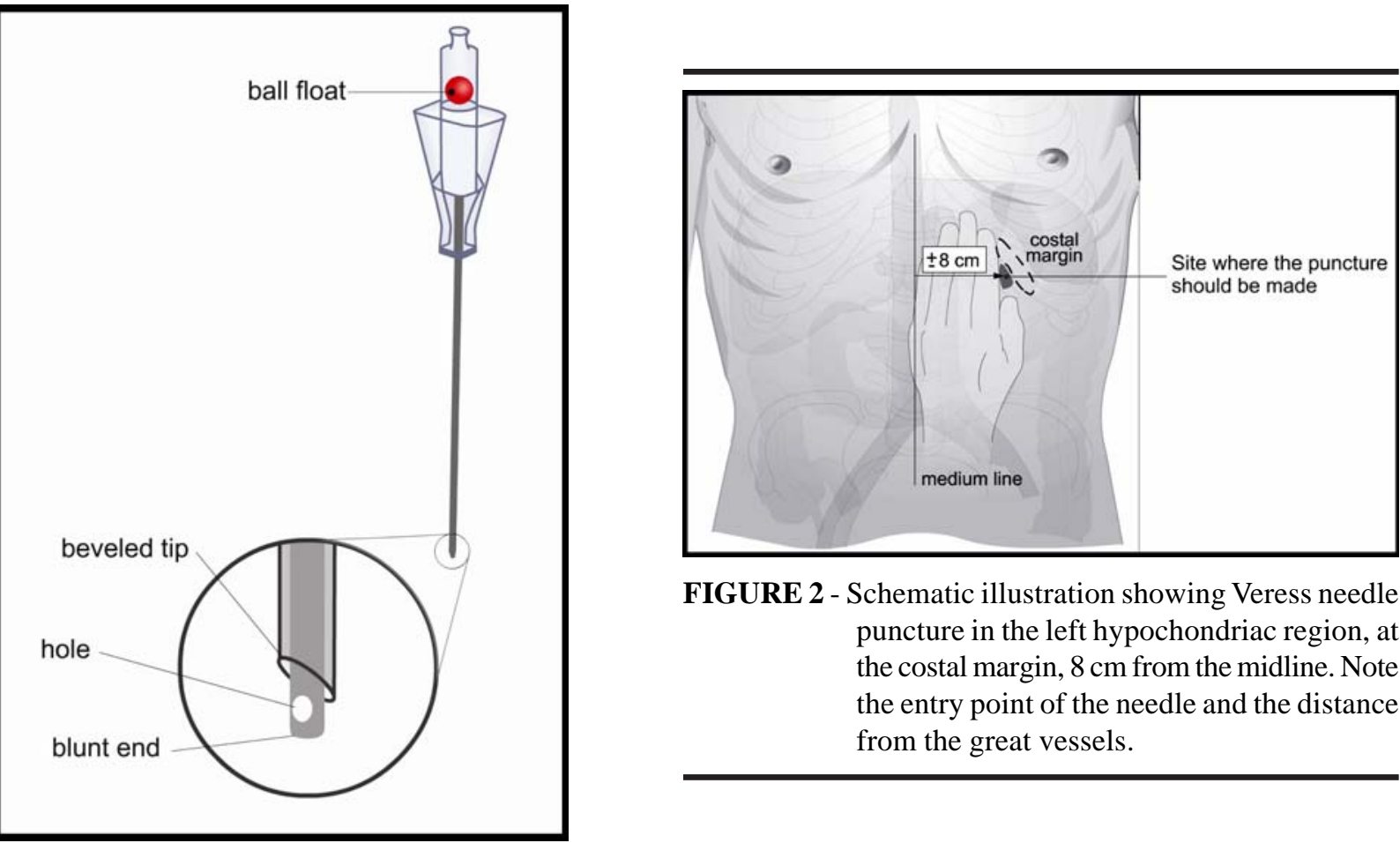

FIGURE 2 - Schematic illustration showing Veress needle puncture in the left hypochondriac region, at the costal margin, $8 \mathrm{~cm}$ from the midline. Note the entry point of the needle and the distance from the great vessels.

FIGURE 1 - The Veress needle

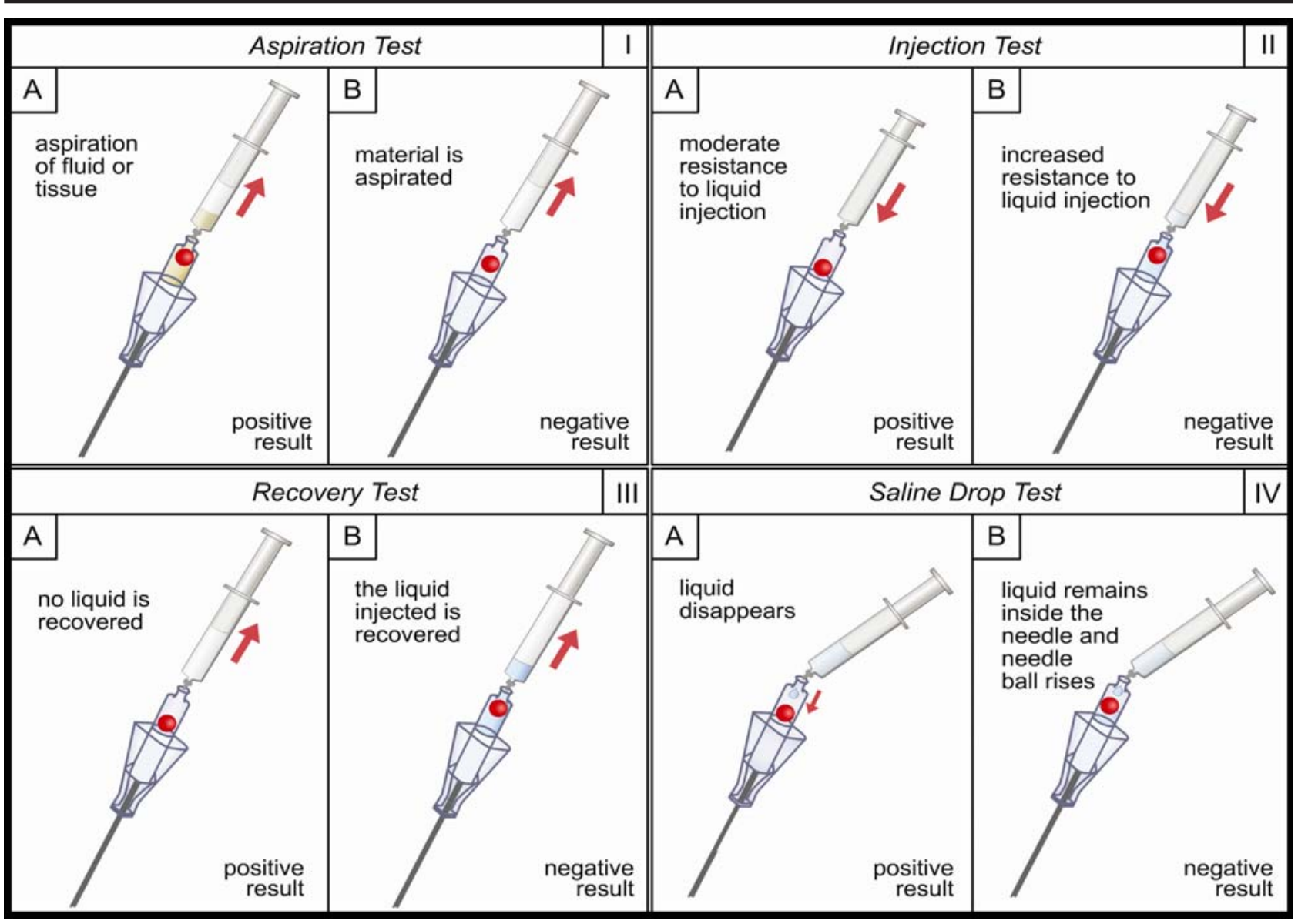

FIGURE 3 - Needle positioning tests: Aspiration test: aspiration using a $5 \mathrm{ml}$ syringe with a Veress needle. This test was considered positive when no material was aspirated (I-A), and negative when any material was aspirated (I-B). Injection test: injection of 5 ml of saline solution through the Veress needle. This test was considered positive when moderate resistance to liquid flow was observed (II-A), and negative when increased resistance to liquid flow was observed (II-B). Recovery test: after injection of 5 ml of saline solution, aspiration was performed. This test was considered positive when the liquid injected was not recovered (III-A), and negative when the liquid was not recovered (III-B). Saline drop test: saline solution was poured into the needle. Liquid flow was observed. This test was considered positive when the liquid disappeared immediately (IV-A), and negative when the liquid remained inside the needle (IV-B) 
This test was considered positive (needle correctly positioned inside the peritoneal cavity with unobstructed side hole) when initial intraperitoneal pressure was $8 \mathrm{mmHg}$ or lower during the first ten seconds of insufflation. When initial intraperitoneal pressure was over $8 \mathrm{mmHg}$ and remained this way for ten seconds, IIPT was considered negative (needle incorrectly positioned inside the peritoneal cavity, or obstruction of its side hole). The needle consists of two cylinders, one inside the other. The outer cylinder is shorter and has a beveled tip. The inner cylinder is longer and has a blunt end with a side hole through which gas flows for intraperitoneal insufflation. A small spring makes it possible for one cylinder to slide over the other. Thus, when there is tissue resistance, the inner cylinder remains inside the outer one. When the needle is inside the peritoneal cavity, the blunt cylinder is advanced outward. When IIPT was considered negative, preventing creation of pneumoperitoneum, the procedure was recorded as a failure, and the Veress needle was removed from the abdominal wall. The procedure started again. When IIPT was considered positive, insufflation continued until intraperitoneal pressure reached $12 \mathrm{mmHg}$. The procedure was recorded as a success when effective creation of artificial pneumoperitoneum was visually confirmed by inserting a laparoscope into the peritoneal cavity. Failed attempts to insert the Veress needle into the peritoneal cavity, as evidenced by each of the tests performed, were computed and tabulated. The results of the tests previously described (positive or negative) were taken into consideration to calculate sensitivity, specificity, positive predictive value (PPV) and negative predictive value (NPV) of each test (Chart 1).
Sensitivity was defined as the proportion of cases in which the test was able to confirm that the Veress needle was correctly positioned, according to the following formula: sensitivity $=$ [true positives $/$ (true positives + false negatives)] x 100. Effective creation of pneumoperitoneum, visually confirmed by inserting a laparoscope into the peritoneal cavity, indicated that the needle was correctly positioned. Specificity was defined as the proportion of cases in which the test was able to confirm that the Veress needle was incorrectly positioned, according to the following formula: specificity $=$ [true negatives / (true negatives + false positives)] x 100 . Inability to effectively insufflate the peritoneal cavity confirmed that the needle was incorrectly positioned. The probability of the needle being correctly positioned among the positive results of a test was considered the positive predictive value (PPV). The probability of the needle being incorrectly positioned among the negative results of a test was considered the negative predictive value (NPV). Both values were used to evaluate the validity of test results, and were calculated according to the following formulas: PPV $=$ [true positives / (true positives + false positives)] x 100; NPV $=$ [true negatives / (true negatives + false negatives)] x 100. The data were submitted to statistical analysis. Qualitative variables were represented by absolute and relative frequencies. Quantitative variables were represented by mean, standard deviation, and minimum and maximum values. Intervals with $95 \%$ confidence level for means and proportions were constructed assuming normal distribution.

CHART 1 - Factors included in the formulas for sensitivity and specificity of needle positioning tests performed after needle insertion to create pneumoperitoneum; positive predictive value (VPP) and negative predictive value (VPN)

\begin{tabular}{|c|c|c|c|}
\hline \multirow{2}{*}{ Results } & \multicolumn{2}{|c|}{ Needle tip inside the peritoneal cavity } & \multirow{2}{*}{ Total } \\
\hline & Present & Absent & \\
\hline Positive test & $\begin{array}{l}\text { a } \\
\text { true positive }\end{array}$ & $\begin{array}{l}\mathrm{b} \\
\text { false positive }\end{array}$ & $\begin{array}{l}\mathrm{a}+\mathrm{b} \\
\text { positive tests }\end{array}$ \\
\hline Negative test & $\begin{array}{l}\text { c } \\
\text { false negative }\end{array}$ & $\begin{array}{l}\text { d } \\
\text { true negative }\end{array}$ & $\begin{array}{l}\mathrm{c}+\mathrm{d} \\
\text { negative tests }\end{array}$ \\
\hline Total & $\begin{array}{l}a+c \\
\text { positive cases }\end{array}$ & $\begin{array}{l}\mathrm{b}+\mathrm{d} \\
\text { negative cases }\end{array}$ & $\begin{array}{l}a+b+c+d \\
\text { cases }\end{array}$ \\
\hline
\end{tabular}

\section{Results}

The maximum number of attempts to create pneumoperitoneum was two per patient. Insufflation of gas into a wrong site did not occur. Among the ten failed attempts observed (Table 2), five were detected by injection test, saline drop test, and initial intraperitoneal pressure test (IIPT). The other five were detected by IIPT. The aspiration test correctly indicated absence of iatrogenic injury. The injection test was not able to detect any of the failed attempts. Recovery and saline drop tests were not able to detect five of the ten failed attempts at reaching the peritoneal cavity, which were later detected by IIPT. Sensitivity, specificity, and positive and negative predictive values are shown in Tables 3 to 6 and Figure 4. 
TABLE 2 - Number of failed attempts to introduce the Veress needle into the peritoneal cavity as detected by each test, and respective confidence intervals

\section{Tests}

( $\mathrm{n}=100$ for each test) Negative results (needle was not in the peritoneal cavity)

\begin{tabular}{lccc} 
& number & Proportion \% & $\mathrm{CI}_{95 \%}$ \\
\hline Aspiration & 0 & 0 & \\
Injection & 0 & 0 & \\
Recovery & 5 & 5 & {$[0,0164 ; 0,1128]$} \\
Saline drop & 5 & 5 & {$[0,0164 ; 0,1128]$} \\
Initial pressure & 10 & 10 & {$[0,0490 ; 0,1762]$} \\
Failures & 10 & 10 & {$[0,0490 ; 0,1762]$}
\end{tabular}

TABLE 3 - Calculation of sensitivity, specificity, positive predictive value (PPV) and negative predictive value (NPV) of the injection test (IT)

\begin{tabular}{lcccr}
\hline \multirow{2}{*}{$\begin{array}{l}\text { Resistance to } \\
\text { injection }\end{array}$} & \multicolumn{4}{c}{ Position of the needle } \\
\cline { 2 - 5 } & $\mathrm{n}$ & $\%$ & $\mathrm{n}$ & $\%$ \\
\hline Negative (failure) & 0 & 0.0 & 0 & 0.0 \\
Positive (success) & 10 & 100.0 & 90 & 100.0 \\
\hline Total & 10 & 100.0 & 90 & 100.0 \\
\hline
\end{tabular}

Sensitivity $=0$; Specificity $=100 \%$; PPV $=$ inexistent; NPV $=90 \%$.

TABLE 5 - Calculation of sensitivity, specificity, positive predictive value (PPV) and negative predictive value (NPV) of the recovery test (RT) and saline drop test (SDT)

\begin{tabular}{lrrrr}
\hline \multirow{2}{*}{$\begin{array}{l}\text { Recovery / Saline } \\
\text { drop }\end{array}$} & \multicolumn{4}{c}{ Position of the needle } \\
\cline { 2 - 5 } & \multicolumn{2}{c}{ Incorrect } & \multicolumn{2}{c}{ Correct } \\
\cline { 2 - 5 } & $\mathrm{n}$ & $\%$ & $\mathrm{n}$ & $\%$ \\
\hline Negative (failure) & 5 & 50.0 & 0 & 0.0 \\
Positive (success) & 5 & 50.0 & 90 & 100.0 \\
\hline Total & 10 & 100.0 & 90 & 100.0 \\
\hline
\end{tabular}

Sensitivity $=50 \%$; Specificity $=100 \%$;PV $=100 \%$;PV $=94.7 \%$.
TABLE 4 - Calculation of sensitivity, specificity, positive predictive value (PPV) and negative predictive value (NPV) of the aspiration test (AT)

\begin{tabular}{lcccc}
\hline \multirow{2}{*}{ Aspiration } & \multicolumn{4}{c}{ Position of the needle } \\
\cline { 2 - 5 } & $\begin{array}{c}\text { Presence of } \\
\text { iatrogenic injury }\end{array}$ & $\begin{array}{c}\text { Absence of } \\
\text { iatrogenic injury }\end{array}$ \\
\cline { 2 - 5 } & $\mathrm{n}$ & $\%$ & $\mathrm{n}$ & $\%$ \\
\hline Positive & 0 & 0.0 & 0 & 0.0 \\
Negative & 0 & 0.0 & 100 & 100.0 \\
\hline Total & 0 & 0.0 & 100 & 100.0 \\
\hline Sensitivity $=$ 0; Specificity $=100 \%$; PPV $=$ inexistent; & NPV $=100 \%$
\end{tabular}

TABLE 6 - Calculation of sensitivity, specificity, positive predictive value (PPV) and negative predictive value (NPV) of the initial intraperitoneal pressure test (IIPT)

\begin{tabular}{lrrrr}
\hline \multirow{2}{*}{ Initial pressure } & \multicolumn{4}{c}{ Position of the needle } \\
\cline { 2 - 5 } & \multicolumn{2}{c}{ Incorrect } & \multicolumn{2}{c}{ Correct } \\
\cline { 2 - 5 } & $\mathrm{n}$ & $\%$ & $\mathrm{n}$ & $\%$ \\
\hline Negative (failure) & 10 & 100.0 & 0 & 0.0 \\
Positive (success) & 0 & 0.0 & 90 & 100.0 \\
\hline Total & 10 & 100.0 & 90 & 100.0 \\
\hline
\end{tabular}

Sensitivity $=100 \%$; Specificity $=100 \%$ PPV $=100 \%$, NPV $=100 \%$.

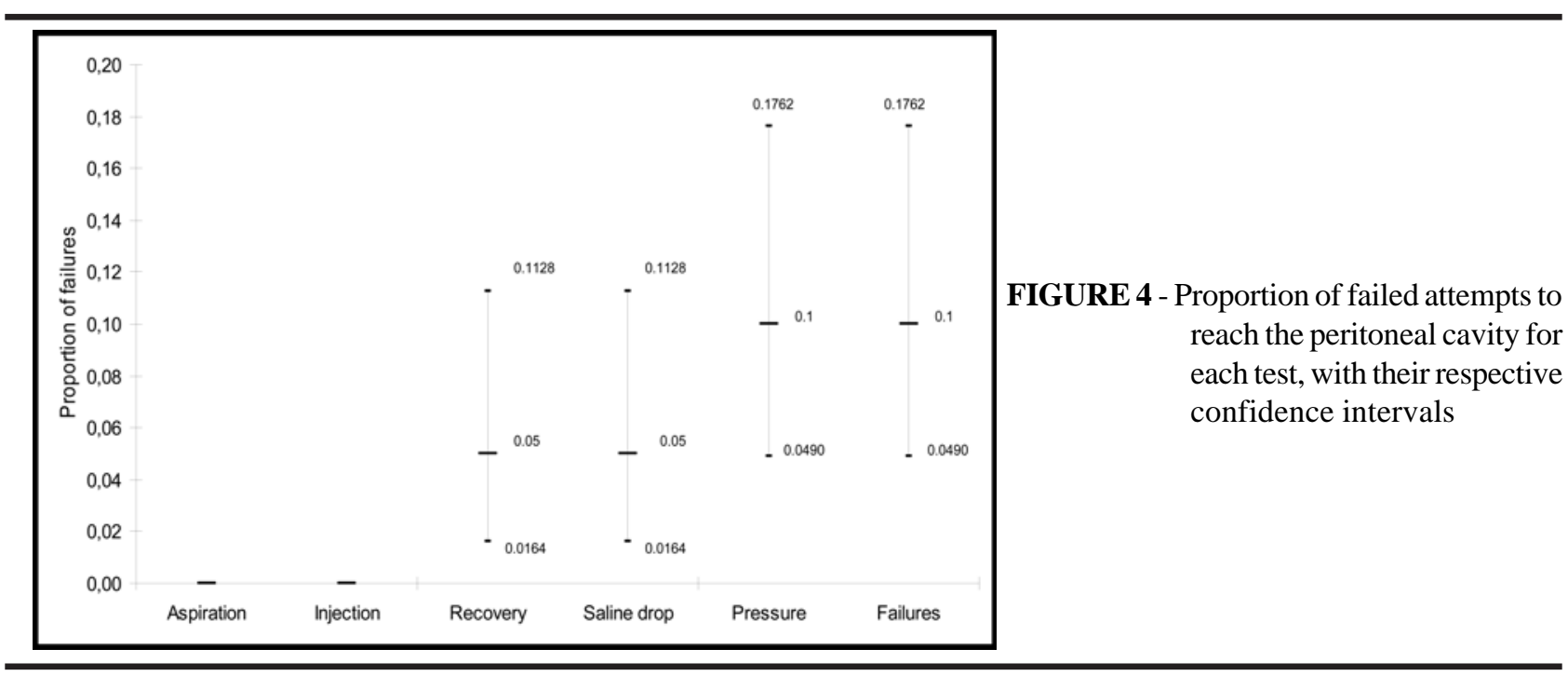




\section{Discussion}

The Veress needle was created in 1938 by Hungarian doctor János Veress to induce pneumothorax in treatment of tuberculosis ${ }^{\mathbf{9 1 0}}$. Today, the needle is used in laparoscopic procedures to gain access to the peritoneal cavity for creation of pneumoperitoneum ${ }^{\mathbf{1 1}}$. The Veress needle can perforate tissues of the abdominal wall with its beveled tip (Figure 1). When it reaches the peritoneal cavity, an inner cylinder with a blunt end is advanced outward. This system is effective and quite safe, making the Veress needle puncture a quick and easy technique for reaching the abdominal cavity ${ }^{\mathbf{1 2}}$. Once the peritoneal cavity is insufflated, the first trocar can be easily introduced; the escape of gas during the procedure is minimized and the operative time is reduced. Nevertheless, major injury to the great vessels caused by the Veress needle is still the main cause of death during laparoscopic procedures ${ }^{3}$. The tests performed to check whether the Veress needle is correctly positioned (closed technique) lack objective criteria of validation. Researches on this topic are found in the literature, but they involve laboratory animals ${ }^{\mathbf{1 3}}$, not humans. Injection, recovery, saline drop and initial intraperitoneal pressure tests were performed to detect whether the tip of the needle was inside the peritoneal cavity. These tests were considered positive when the observed phenomena led us to assume that the needle was inside the peritoneal cavity. The tests were considered negative when the observed phenomena led us to assume that the needle rested in any site other than the peritoneal cavity. The aspiration test was performed with the specific purpose of diagnosing iatrogenic injury that might have occurred very early in the procedure. This test was considered positive when the tip of the needle was undeniably inside a parenchymatous organ, hollow viscera or blood vessel, which could be detected by the aspiration of fluid or organic tissue. The aspiration test has distinctive characteristics because it is designed to identify the presence or absence of iatrogenic injury, not to check whether the needle is correctly positioned. To better evaluate the tests, we tried to fit the results obtained into mathematical and statistical criteria that could lend credibility to and ensure the accuracy of our conclusions. With regard to the positioning of the Veress needle, the ideal test is that which, when positive, indicates without a doubt that the tip of the needle is inside the peritoneal cavity and, when negative, that it is not. Thus, the tests were evaluated according to their sensitivity (the ability to detect true positives), specificity (the ability to detect true negatives), positive predictive value (the probability of the needle being correctly positioned among the positive results obtained), and negative predictive value (the probability of the needle being incorrectly positioned among the negative results obtained). With regard to injection, recovery, saline drop and initial intraperitoneal pressure tests, true positives were visually confirmed by inserting a laparoscope into the peritoneal cavity after the pneumoperitoneum had been established. True negatives were confirmed either by the impossibility of establishing pneumoperitoneum or by insufflation of gas into an inadequate site. The present study allowed us to conclude that, when inserting the Veress needle into the left hypochondrium to create artificial pneumoperitoneum, a negative aspiration test guarantees the absence of iatrogenic injury (excellent specificity); the injection test is not reliable to determine that the needle is incorrectly positioned, but it accurately detects the presence of the needle tip in the peritoneal cavity (good sensitivity); recovery and saline drop tests are not reliable to determine that the needle is correctly positioned, but they accurately detect the absence of the needle tip in the peritoneal cavity (good specificity); the initial intraperitoneal pressure test is reliable to determine both correct and incorrect needle positioning (excellent sensitivity and specificity), and proved to be the most reliable of the tests analyzed. Overall, the five tests evaluated in this study are adequate to guide surgeons with regard to the correct positioning of the Veress needle for creation of pneumoperitoneum. These tests may avoid iatrogenic injury and insufflation of gas into the wrong site.

\section{References}

1. Merlin TL, HillerJE, MaddernGJ, Jamieson GG, Brown AR, Kolbe A. Systematic review of the safety and effectiveness of methods used to establish pneumoperitoneum in laparoscopic surgery. Br J Surg. 2003;90:668-9.

2. Neudecker J, Sauerland S, Neugebauer E, Bergamaschi R, Bonjer H, Cuschieri A. The European Association for Endoscopic Surgery clinical practice guideline on the pneumoperitoneum for laparoscopic surgery. Surg Endosc. 2002;16:1121-43.

3. Catarci M, Carlini M, Gentileschi P, Sanroro E. Major and minor injuries during the cration of pneumoperitoneum. Surg Endosc. 2001;15:566-69.

4. Molloy D, Kaloo PD, Cooper M, Nguyen TV. Laparoscopic entry: a literature review and analysis of techniques and complications of primary port entry. Aust N Z J Obstet Gynaecol. 2002;42:246-53.

5. Azevedo OC, Azevedo JLMC, Sorbello AA, Godoy AC, Menezes FJC, Aguiar GS. Criação do pneumoperitônio mediante punção com agulha de Veress no hipocôndrio esquerdo: ensaio clínico, prospectivo e randomizado. Rev Col Bras Cir. 2005;32:273-8.

6. Peterson HB, Greenspan JR, Ory HW. Death following puncture of the aorta during laparoscopy sterilization. Obstet Gynecol. 1982;59:133-4.

7. Pirró N, Ciampi D, Champsaur P, Mariano VD. The anatomical relationship of the iliocava junction to the lumbosacral spine and the aortic bifurcation. Surg Radiol Anat. 2005; 27:137-41.

8. Schafer M, Lauper M, Krahenbuhl L. Trocar and Veress needle injuries during laparoscopy. Surg Endosc. 2001;15:275-80.

9. Veress J. Neues Instument zur Ausfuhrung von Brustoder Bauchpunktionen und Pneumothoraxbehandlung. Dtsch Med Wochenshr.1938;41:1480-1. 
10. Bridgewater FH, Mouton WG. Rationale and intended use for the Veress needle: A translation of the original descriptive article. Surg Laparosc Endosc. 1999;9:241-4.

11. Santor J, Ballagi F, Nagy A, Rákóczi I. A needle-puncture that helped to change the world of surgery. Surg Endosc. 2000;14:201-2.

12. Chandler JG, Corson SL, Way LW. Three spectra of laparoscopic entry access injuries. J Am Coll Surg. 2001;192 :478-91.
13. Azevedo JLMC, Guindalini RSC, Sorbello AA, Silva CEP, Azevedo OC, Aguiar GS, Menezes FJC, Delorenzo A, Pasqualin RC, Kozu FO. Evaluation of the positioning of the tip of the Veress needle during creation of closed pneumoperitoneum in pigs. Acta Cir Bras. 2006,21:26-30.

\section{Correspondence:}

Prof. Dr. João Luiz M. C. Azevedo

Disciplina de Técnica Operatória e Cirurgia Experimental

Universidade Federal de São Paulo

Rua Botucatu, 740

4023-900 - São Paulo - SP Brazil

jozevedo.dcir@epm.br
Conflict of interest: none Financial source: none

Received: June 8, 2006

Review: July 18, 2006

Accepted: August 23, 2006

\section{How to cite this article:}

Azevedo OC, Azevedo JLMC, Sorbello AA, Miguel GPS, Wilson Jr JL, Godoy AC. Evaluation of tests performed to confirm the position of the Veress needle for creation of pneumoperitoneum in selected patients: a prospective clinical trial. Acta Cir Bras. [serial on the Internet] 2006 Nov-Dec;21(6). Available from URL: http://www.scielo.br/acb.

\section{AVISO AOS AUTORES}

Solicita-se aos autores observarem o estilo e as normas da revistas Acra Cirurgica Brasileira. Consultar os artigos publicados em fascículos recentes da revista.

Acessar http://www.scielo.br/acb - Instruções aos autores.

Informações adicionais pelo e-mail sgolden@terra.com.br

\section{RECOMENDAÇÕES AOS AUTORES}

OS DESCRITORES/KEY WORDS são essenciais para a acessibilidade e recuperação dos artigos.

O DeCS (Descritores em Ciências da Saúde) facilita o acesso a informação e guia os usuários na localização e seleção da informação científica.

Incluir termos, nos descritores, que não estão no DeCS impedem a localização do artigo.

Se os autores desejarem que seus artigos sejam encontrados torna-se imperioso pesquisar no DeCS os termos corretos.

Acessar www.bireme.br e clicar em Terminologia em Saúde. A seguir consula ao DeCS e por fim consulta por palavra nos idiomas inglês, espanhol e português. 